\title{
The Effect of Monetary Policy Indicators Analysis by Using Interest Rate and Money Supply Approach to the Inflation in Aceh
}

\author{
Leli Putri Ansari \\ \{leli.putri.ansari@gmail.com, leliputriansari@utu.ac.id\} \\ Economic Faculty,Teuku Umar University, Aceh, Indonesia
}

\begin{abstract}
Since 2005, Bank Indonesia as the Monetary Authority has implemented a monetary policy framework whose main objective is to maintain inflation rate in line with the stipulated by the government. The monetary policy indicators used to achieve these objectives are the interest rate and money supply approaches, in which Bank Indonesia can choose one of the indicators of the monetary policy. The purpose of this study is to analyze how the influence of monetary policy with the approach of interest rates and money supply to the inflation in Aceh. This analysis uses interest rates and money supply as an independent variable, while inflation as a dependent variable. The research method used is quantitative in the form of secondary data. The data analysis model uses multiple linear regression. The results obtained that the monetary policy with the interest rate approach has a significant effect and the relationship is positive to inflation. This means that if interest rates rise then inflation is high, and vice versa if interest rates fall then inflation is low. it should be the relationship between interest rates with inflation is negative. Furthermore, monetary policy with money supply approach has a significant effect and negative relation to inflation. This means that if the money supply is high, then the inflation is low, and vice versa if money supply is little then the inflation is high. Therefore, it is better for Bank Indonesia to choose monetary policy indicator with money supply approach in order to achieve the target to keep inflation rate as determined by the government.
\end{abstract}

Keywords: Interest rates, money supply, and inflation

\section{Introduction}

Inflation is a general increase in the price level of goods and services in a certain period. Inflation can be considered a monetary phenomenon because of a decrease in the value of monetary calculation unit toward an item and service and the level of purchasing power of people, especially permanent income workers.

Inflation rates that occur in Indonesia often fluctuate from year to year due to the overindulgence of the Indonesian economy towards influences originating within the country and from abroad. Therefore, in 2005 Bank Indonesia as a Monetary Authority implemented a monetary policy framework with inflation as its main target in order to achieve the inflation target as set by the government, by implementing monetary policy indicators on the interest rate and money supply approach.

In 2016, inflation in Aceh was 3.73 percent, the biggest contributor to this inflation was the food group and inflation in Indonesia was at 3.02 percent. Thus, the purpose of this study is to analyze how the influence of monetary policy indicators with the interest rate approach and money supply toward inflation in Aceh. 


\section{Literature Review}

\subsection{Inflation Theory}

The inflation theory provides an illustration of why inflation occurs. The quantity theory explains that inflation occurs because of the addition of the money supply volume (the addition of currency and demand deposits) as well as the public's expectation of rising prices in the future (expectations). The addition of the money supply in the community will affect the value of money and the price of goods and services in the economy. The Keynesian theory explains that inflation occurs because a group of people such as the government, private companies and laborers want to live outside the limits of their economic capacity, resulting in an inflationary gap that is a condition in which public demand for goods exceeds the amount of available goods. The government is trying to get a greater share of the people's output by running a deficit in its spending budget financed by printing new money. Private companies make new investments and obtain funding from bank loans. Trade unions that are trying to get salary increases for their members exceed the increase in labor productivity. If the number of requests are effective from all groups of people, there will be an inflationary gap. Furthermore, according to the structuralism theory, inflation occurs because first, if the money supply continues to increase and passively follows and accommodates the price of goods; second, inflation is caused by the price or monetary policy of the government itself, such as the inability of domestic food production to grow due to the suppression of food prices in the country, so that the production of farmers is reduced; third, inflation occurs because the inability to produce exported goods to grow, it is because the foreign exchange rate is pressed too low with the aim of reducing inflation and the existence of illegal payments so that the prices of export goods are really received by the low producers, thereby reducing production enthusiasm. (Silalahi, 2013, pp. 214-224).

\subsection{Types of Inflation}

According to Robert J Barro in (Adiwarman, A., 2015, pp. 137-139) types of inflation can be seen from their causes and severity. When viewed from the cause, inflation is mild (moderate inflation) characterized by an inflation rate of less than 10 percent per year and generally at this inflation rate, people still want to hold money and save their wealth in the form of money rather than in the form of real assets and this inflation has not disturbed the economy. Then inflation is (galloping inflation) marked a significant price increase with the inflation rate ranging from 20 percent to 200 percent per year and people only want to hold money as needed while wealth is stored in real assets and people will tend to want their funds to invest abroad rather than invest domestically, this inflation usually results in major disruptions to the economy. High inflation (hyper inflation) occurs at a very high level of millions to trillions of percent per year. This condition arises when the government experiences a budget deficit. Furthermore, inflation is seen from the first cause of natural inflation, which is inflation that occurs due to natural causes that humans do not have the power to prevent. Both demand pull inflations are inflation caused by changes in the aggregate demand side of goods and services in an economy. The third cost push inflation is inflation that occurs due to changes in the aggregative supply side (US) of goods and services in an economy. The fourth spiraling inflation is inflation caused by inflation that occurred before which the previous inflation occurred as a result of previous inflation again and so on. These five imported inflation are inflation that occurs due to inflation in other countries that are experienced by a country because they must be price leaders in the international trade market. 
The seven domestic inflation are inflation that only occurs in a country and does not affect other countries.

\subsection{How to Control Inflation}

According to (Nopirin, 2000, p. 34) that the way to control inflation can be done through the first monetary policy, namely policies relating to the regulation of the money supply carried out by Bank Indonesia and the form of implementation of monetary policy instruments including open market operations affecting the amount of money circulating, discount rate affects the cost of money, the minimum reserve requirement affects the amount of minimum third party funds that must be kept because it cannot be channeled as credit by the bank, then moral suasion that influences the actions of bankers and senior managers of financial institutions in their daily business operations so that they are in line with government interests. Both fiscal policies relate to how the government finances its expenditure as an effort to control inflation such as the government can withdraw taxes or sell bonds in the country, so that the effect of inflation is small. The three policies related to output, namely an increase of output can reduce the rate of inflation. The increase in the amount of output can be achieved through a policy of reducing import duties and smooth administration of imports so that imported goods tend to increase at low cost. Increasing domestic goods tends to reduce prices. Fourth is the pricing policy, namely the government directly engages in market operations to control prices and the government also provides information on the price of basic necessities so that it can reduce speculation on the market. The five general policies are the policy to slowly improve the structure of the economy which is less flexible in dealing with existing economic developments. The examples of this form of general policy investment are policies for infrastructure improvements, improvements in licensing, taxation, capital markets, efficiency of bureaucracy, banking, and agriculture so those policies can reduce inflation.

\subsection{Interest Rate Theory}

Mc.Kinnon in (Sugiyanto, 1993, p. 114) describes the interest rate in developing countries with the assumption that financial institutions in developing countries can carry out their functions properly as intermediaries between savers and investors. Investors save first and then can make investments to buy capital goods. To stimulate savings mobilization, real interest must be positive. In order to create a positive real interest rate, the nominal interest rate must be higher than the rate of inflation. Whereas according to the loanable funds theory that the interest rate is determined by the amount of requests and offers for loanable funds. The loanable funds demand component consists of public demand for investment purposes as well as to hold cash, and the loanable funds offer component consists of government and community national savings, foreign balance of payments surplus (net exports and net capital traffic), as well as domestic credit monetary authority. The greater the additional domestic credit of monetary authorities and the foreign balance of payments surplus, the greater the additional loanable funds so that interest rates can be reduced. Furthermore, according to Keynes's theory that interest rates are determined by the interaction between the real sector and the monetary sector. Keynes assumed that the economy had not reached the level of full employment. Therefore production can still be increased without changing wage rates or price levels, by reducing interest rates, investment can be stimulated to increase national production. To sum up, monetary policy plays a role in increasing national production. However, after the economy is in full employment, monetary policy cannot play a role to increase national production anymore. 


\subsection{Money Supply}

The money supply consists of M1, M2, M3. M1 includes currency held by the public and demand deposits in the form of rupiah-denominated demand deposits. M2 includes M1, time deposits, the balance of savings owned by the public in banks in rupiah. M3 includes M1, M2 and all time deposits, the balance of savings in rupiah or dollar owned by the community at banks or non-bank financial institutions.

\subsection{Monetary Policy Indicator}

The monetary policy indicator is an intermediate target (intermediate target) to measure the extent to which the achievement of monetary policy objectives is achieved. There are two indicators of monetary policy used, namely interest rates and money supply. If monetary policy indicators use interest rates as intermediate targets, Bank Indonesia will set an ideal interest rate to encourage investment activities. If the interest rate shows an increase exceeding the predetermined number, then Bank Indonesia conducts monetary expansion so that the interest rate falls to the specified level, otherwise if the interest rate falls below the predetermined rate then Bank Indonesia will conduct a monetary contraction. Furthermore, if the monetary policy indicators used in the money supply as intermediate targets will have a positive impact, namely a stable price level. If there is a turmoil in the money supply which exceeds or is less than the money supply that has been determined, Bank Indonesia will contract or expand monetary so that the money supply will remain at a fixed amount (Pohan, 2008 , p. 41). Based on the description that has been explained, the formulation of the hypothesis is assumed that the monetary policy indicator with the interest rate and money supply approach influences of inflation in Aceh.

\section{Methodology}

This study uses secondary data from 2005 to 2016 sourced from the Central Statistics Agency (BPS) downloaded via the website https://aceh.bps.go.id and Bank Indonesia (BI) downloaded via the website https://www.bi.go.id, then processed using the program E-views software. The data analysis model in the form of multiple linear regression (OLS) is transformed in the form of semi logaritma (semi log) can be written as follows:

$\operatorname{Inf}=\beta 0+\beta 1 \mathrm{R}+\beta 2 \log \mathrm{UB}+\mathrm{Ui}$

Where :

Inf is inflation, $\beta 0$ is a constant, $\beta 1, \beta 2$ is the regression coefficient, $\mathrm{R}$ is the interest rate, UB is the money supply.

\section{Result And Discussion}

Actual inflation in Aceh 2005 to 2008 exceed inflation target. The highest actual inflation in Aceh occurred in 2005 and in 2008 exceeding the inflation target set by the government. This was due to 2005 the economic condition of the Aceh experienced a recession after the tsunami and rising fuel prices, where inflation target is 6 percent and actual inflation is 29.93 percent. In 2008, world crude oil prices rose so fuel prices also rose and were followed by economic turmoil, namely the rupiah depression, where inflation target is 5 
percent and actual inflation is 11.94 percent. But in 2009 to 2016 actual inflation was below the inflation target. This is because demand for goods is lower than the supply, and inflation expectations from the public are low. This can be seen in Table 1.

Table 1. Ratio Inflation Target and Actual Inflation In Aceh Year 2005 -2016

\begin{tabular}{rrr}
\hline Year & Inflation target (\%) & Actual inflation (\%) \\
\hline 2005 & 6 & 29,93 \\
\hline 2006 & 8 & 10,46 \\
\hline 2007 & 6 & 7,76 \\
\hline 2008 & 5 & 11,94 \\
\hline 2009 & 4,5 & 3,72 \\
\hline 2010 & 5 & 5,85 \\
\hline 2011 & 5 & 3,43 \\
\hline 2012 & 4,5 & 2,26 \\
\hline 2013 & 4,5 & 7,31 \\
\hline 2014 & 4,5 & 7,73 \\
\hline 2015 & 4 & 3,87 \\
\hline 2016 & 4 & 3,73 \\
\hline \multicolumn{3}{c}{ Source $:$ BPS. https://aceh.bi.go.id }
\end{tabular}

The focus of this study is base money consisting of currency and current account balances with Bank Indonesia in Aceh because Bank Indonesia usually controls money supply through the regulation of base money. While the interest rate used in this study is the interest rate set by Bank Indonesia. The development of circulating money in 2005 to 2016, this can be seen in the following figure 1 :

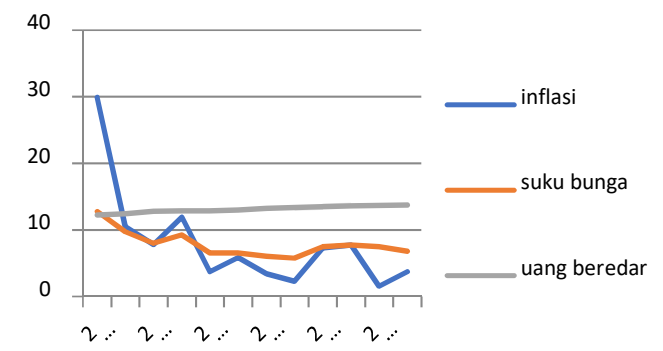

Fig. 1. The Development Money Supply (Base Money), Interest Rate and Inflation in Aceh (Source : Bank Indonesia. https://www.bi.go.id)

The development of circulating money in 2005 to 2016 continued to increase due to the need for people to make money in the larger transactions offset by an increase in per capita income, but interest rates and inflation fluctuated. The highest interest rate occurred in 2005 at 12.75 percent. This high interest rate was set by Bank Indonesia to control inflation. In 2005 the money supply was less than IDR 204,539.75 compared to 2006 amounting to IDR $250,779.75$ billion. But higher inflation occurred in 2005 of 29.93 percent compared to inflation in 2006 of 10.46 percent. This was due to the fact that in 2005 the economic condition of Aceh Province was still not stable after the tsunami due to the high demand for basic necessities and an increase in the price of fuel oil. However, in 2006, the economy of 
Aceh began to improve, and land transportation became smoothly so that the total demand for staple goods was fulfilled.

Table 2. Estimation Output

\begin{tabular}{lllll}
\hline Variable & Coefficient & Std.Error & t-Statistic & Prob \\
\hline C & 7.949701 & 36.17052 & 0.219784 & 0.8309 \\
\hline INTEREST & 3.284902 & 0.618719 & 5.309201 & 0.0005 \\
\hline BI_RATE & & & & \\
\hline BASED & -1.962517 & 2.492259 & -0.787445 & 0.4513 \\
\hline R-squared & 0.879671 & & & \\
\hline Adjusted R-squared & 0.852931 & & & \\
\hline S.E of regression & 2.925107 & & & \\
\hline Sum squared resid & 77.00626 & & & \\
\hline Log likelihood & -28.18114 & & & \\
\hline F-statistic & 32.89744 & & & \\
\hline Prob (F-statistic) & 0.000073 & & & \\
\hline Durbin-Watson stat & 2.042561 & & & \\
\hline Hannan-Quinn criter & 5.151975 & & & \\
\hline Schwarz criterion & 5.318084 & & & \\
\hline Akaike info criterion & 5.196857 & & & \\
\hline S.D dependent var & 7.627484 & & & \\
\hline Mean dependent var & 7.970833 & & & \\
\hline
\end{tabular}

Source : Authors Estimation

Based on Table 2, the multiple linear regression equation can be written as follows: Inf $=7,94970+3,284902$ R-1,962517 UB

The equation (2) can be concluded that a constant of 7.94970 means that if the monetary policy indicator with the interest rate and money supply approach equals zero then there will be an inflation of 7.94970. Furthermore, the coefficient of the monetary policy indicator with an interest rate approach of 3.284902 has a significant influence on the real level of 5 percent and a positive relationship to inflation, it means that if inflation is high then Bank Indonesia will raise interest rates, thus it encourages people to save money in the bank expecting profits, and vice versa if inflation is low, Bank Indonesia will reduce interest rates, thus it encourages investors to borrow money from banks to invest. This result is consistent with the research conducted by (Langi, Masinambow and Siwu, 2014) that interest rates have a positive effect on inflation. While the coefficient of monetary policy indicators with the money supply approach is -1.962517 and has no significant effect on the 1 percent, 5 percent and 10 percent real level and a negative relationship to inflation, meaning that if inflation is high then Bank Indonesia will reduce the money supply and on the contrary if inflation is low then Bank Indonesia will increase the money supply. Monetary policy indicators with the money supply approach do not have a significant effect on inflation because the state of Aceh's economy is more sensitive to the turmoil in the money market than the goods market such as a lot of funds settling in Aceh-owned banks and communities so that the economic turnover in Acehnese society and the funds by the bank placed in the form of Bank Indonesia Certificates (SBI). The results of this study are also in line with the research conducted by (Luwihadi and Arka, 2014) which the result of their study was money supply has no significant effect on inflation. 
Adjusted R square value obtained at 0.852931 shows that the magnitude of the influence of monetary policy indicators with the interest rate and money supply approach to inflation is 85.92 percent and the remaining 14.08 percent is influenced by other variables outside the model.

\section{Conclusion}

Based on the research that has been done, it can be concluded that monetary policy indicators with an interest rate approach have a significant effect and positive relationship to inflation. While the monetary policy indicator with the money supply approach does not have a significant effect and negative relationship to inflation. This is due to the economic conditions in Aceh Province that are more sensitive to the turmoil in the money market rather than the goods market. If the economic situation is more sensitive to money market turmoil, monetary policy indicators with an interest rate approach are more effective in controlling inflation. If the economic situation is more sensitive to commodity market turmoil, then the monetary policy indicator with the money supply approach is more effective in controlling inflation.

\section{Suggestion}

In controlling inflation and achieving the inflation target or goal as determined by the government, Bank Indonesia should continue to improve banking supervision in terms of lending, and establish good coordination with the government. The government should continue to supervise the distribution of goods, especially basic needs to avoid the black market and set a maximum price.

\section{References}

[1] Adiwarman, A., K. (2015) Islamic Macroeconomics. Jakarta: Rajawali Press.

[2] Langi, T. ., Masinambow, V. and Siwu, H. (2014) 'The Analysis Effect of Interest BI rate, Money Supply, And Kurs Rate to The Inflation In Indonesia', Journal Periodically Scientific Efficient, 14, pp. 44-58.

[3] Luwihadi, N. L. A. and Arka, S. (2014) 'Determinan Jumlah Uang Beredar dan Tingkat Inflasi di Indonesia Periode 1984-2014', EP-Jurnal EP Unud, 6(4), pp. 533-563.

[4] Nopirin (2000) Monetary Economy. Yogyakarta: BPFE.

[5] Pohan, A. (2008) Monetary Policy Framework \& Implementation in Indonesia. Jakarta: Raja Grafindo.

[6] Silalahi, R. (2013) Macroeconomy of Theory. Bandung: Citapustaka Media Perintis.

[7] Sugiyanto, C. (1993) Money Economic and Bank. Jakarta: Gunadarma. 
